terminal one. In this case too, where but one flower formed, the growing point started at nearly a right angle to the original peduncle, and then, curving to bring itself in the same straight line, grew into a strong shoot, forming at its apex a good bud (flower) for the winter.

A similar growth of the calyx into actual leaves occurred in another case.

The last irregularity to which I shall refer is, where the axis of a flower grew into a strong leafy shoot. In this case no cup-like receptacle existed, but the carpels were placed on a disk-like expansion surrounding the stem, which appeared little more than a large node from which the leaves had fallen. The carpels here extended upwards in a green, leafy form, and were deficient of ovules. Eight such, with dilated, capsule-like bases, were found in a whorl on the same plane ; and within these, two close together, longer and of a more leaf-like character. Above these last, five more evident leaves, four of which were actually trifoliate, were disposed in a spiral manner around the axis for the space of an inch above the carpellary whorl. Then a node occurred, surrounded by six pinnate leaves, not quite on the same plane, and yet not in opposite pairs, nor clearly spiral in position. Three-quarters of an inch from these leaves the shoot ended by a terminal bud (winter) surrounded by three pinnate leaves of unequal size.

These instances of monstrosity well illustrate the morphology of carpels-their origin from leaves, and their tendency to take on the form, and along with this, the spiral arrangement of the latter. The perfect pinnate leaves of a shoot proceeding from the centre of a rose we must suppose to be morphologically the same with the small folded carpellary leaf; the last instance cited shows the grades of development between the two.

The production of the shoot causes the abortion of the flower and its ovules ; hence the size and vigour of the shoot afford a measure of the vital vegetative force expended in the formation of a flower, and mainly of its ovules.

I am inclined to believe with Schleiden, that the ovule is a product of the axis and not of the carpellary leaves; that indeed it is a bud growing from the axis in the axil of a leaf-i.e. the carpel.

On the Change of Colour in a Chamaleon (Chamæleo vulgaris). By H. N. Turner, Jum.

Notwithstanding that the peculiarity of the Chamæleon in changing its colour is so universally known, and that an illustrated work on the subject was prublished by Van de Höven, I have thought that a careful record of the varieties of tint, presented by the specimen which has lived for some time in my possession, might prove serviceable to the naturalist if compared with similar observations upon other species and upon the same one under different circumstances, and might also assist in the determination of the means by which it is effected, the influences by which it is regulated, and the objects which it serves in the œconomy of the animal. 
Its general tints vary between different shades of brown, olive, yellow, and light green, the last-named being the most rarely observed, and the yellow being the tint usually assumed when the animal has been hidden from the light. This is the colour it always presents if taken for inspection at night, and when brought into the influence of lamp-light it appears at first almost white, but may soon be seen to darken and some of the markings to appear. The side that is next the light will change rather sooner than the other, the changes being always gradual. It has three distinct sets of markings, the first to appear being two ranges of irregular distant elongated spots, which may appear either as a dark tint upon the ground-colour when that is light, or a light one if it be dark. These marks are never entirely absent when either of the other sets is present, although sometimes but faintly discernible.

The other two sets of markings consist of an irregular marbling, and a number of full round spots ; the latter never appear otherwise than as dark upon the ground-colour, and the marbling, which is generally also dark, only occasionally appears a little lighter than the ground-colour, and then of a different tone; either may be visible without the other, or both may be distinctly traceable. Sometimes the marbling will be apparent together with such of the spots as are placed within its intervals, those upon the surface occupied by the marbling being amalgamated with it.

When the general colour is light yellow or pale greenish, which is the case if the animal be suddenly brought into the light, the elongated spots, which form two rows on each side, will begin to appear of a very delicate purple tint. After that the marbling gradually shows itself, and the general tint begins to darken; when some time has elapsed a brown colour is assumed, and the elongate spots, at first purple of a darker tint than the yellow ground-work, are seen to be brown, of a lighter and rather richer tint than that which now pervades the whole. These distinctions may go on increasing, may then decrease and again increase ; the spots may appear, may come and go with different degrees of intensity, so that the variety of appearances presented is almost indefinite. When visited in the day-time, the colour is generally brown, sometimes without markings, generally with the elongate spots of a lighter tint, and the marbling or the round spots, or both, more or less apparent. Occasionally it presents a uniform dull olive, and then has no markings. Sometimes it is of a light drab colour, with the different marks faintly indicated. The ventral series of prominent scales remains constantly white, as stated by Van der Höven, not participating in the changes of the surrounding parts.

This author does not in any of his plates represent the longitudinal rows of markings as a decided dark upon the ground-colour, nor is the marbling anywhere clearly shown as pervading the whole body ; neither does he give the deep brown tint with the marbling as a dark, and the longitudinal rows of spots definitively marked as a light.

I have never seen my specimen present anything like the appearances delineated in his plates 4 and 5 , probably because $I$ have not irritated it. 
It has generally been imagined that the purpose of this singular faculty accorded to the Chamæleon is to enable it to accommodate its appearance to that of surrounding objects, but the observations of Van der Höven seem to negative that idea, and the few experiments I have made with that view have not led to any such results. The box in which it is kept is of deal, with a glass at the top and a piece of flannel laid at the bottom; a small branching stick being introduced by way of a perch. I have introduced at various times pieces of coloured paper, covering the bottom of the box, of blue, yellow and scarlet, but without the slightest effect upon the appearance of the animal. Considering that these primary colours were not such as it would be likely to be placed in contact with in a state of nature, I next tried a piece of green calico, but equally without result. The animal went through all its usual changes, without their being in any way modified by the colours placed underneath it. The general tints approximate, as may readily be observed, to those of the branches of trees, just as those of most animals do to the places in which they dwell; but I have never seen the faculty of changing called into play with any apparent object. It is only when the light is removed that the animal assumes a colour which absorbs but little of it.

Regretting that I have not been able to attain any more definite conclusions, I offer these few remarks, hoping that to some naturalist, who may undertake the investigation of these singular phænomena, they may prove not to have been thrown away.-Proc. Zool. Soc. July $22,1851$.

\section{Notes on a new species of Artamus, from India.}

By Dr. Nicholson.

These birds are only found in very thick jungles among the brushwood, where they are always moving about, and are shot with great difficulty, and even then, if not killed outright, they are so tenacious of life, that they creep into the first hole or crevice they come to. The only note I ever heard was like 'chick, chick.' I think they are residents, but the few I have seen just appear and are lost again in a moment, so that I know little of their habits; the one described here had one leg and both wings broken, and still crept into the hole of a jerboa-rat, from which I dug it out dead.

Male : weight $6 \frac{1}{2} \mathrm{oz}$.

Length from bill to tip of tail $7 \frac{2}{8}$ inches. Alar extent 10 inches.

Head large. Bill strong, narrow and sharp, gently arched on the culmen; a distinct notch near the tip of upper mandible; gape wide. Tongue horny and divided at the point. Nostrils basal, small. Eye rather small. Iris of a silvery colour, tinged with yellow.

Wings rounded; first quill very short; third longest; second, third and fourth quills emarginate on outer web.

Tail short, and nearly even at the end, of twelve feathers, $2 \frac{3}{4}$ inches long.

Tarsus strong. Hallux and claw stronger than the other toes, and 


\section{$2 \mathrm{BHL}$ Biodiversity Heritage Library}

Turner, H. N. 1853. "On the change of colour in a chamæleon (Chamæleo vulgaris)." The Annals and magazine of natural history; zoology, botany, and geology 12, 292-294. https://doi.org/10.1080/03745485709495042.

View This Item Online: https://www.biodiversitylibrary.org/item/46590

DOI: https://doi.org/10.1080/03745485709495042

Permalink: https://www.biodiversitylibrary.org/partpdf/22694

\section{Holding Institution}

Natural History Museum Library, London

\section{Sponsored by}

Natural History Museum Library, London

\section{Copyright \& Reuse}

Copyright Status: Public domain. The BHL considers that this work is no longer under copyright protection.

This document was created from content at the Biodiversity Heritage Library, the world's largest open access digital library for biodiversity literature and archives. Visit BHL at https://www.biodiversitylibrary.org. 